\title{
THE GROWING CONTEXT OF AGRICULTURAL FINANCE IN INDIA
}

\section{NIKHIL KANDWAL}

Symbiosis Institute of Business Management (SIBM), Symbiosis International (Deemed University) (SIU), Electronics City,

Hosur Road, Bengaluru, Karnataka, India

\begin{abstract}
Agricultural financing is significant, as are the instruments used in agricultural production. The emphasis on the structural structure for agricultural loans was put on understanding the importance of agricultural loans to sustain agriculture production after the beginning of the expected growth cycle in India. This paper discusses the past and needs of Indian farm finance, origins and scale of farm finance, and reviews the growth of farming finance. The paper is focused on secondary information gathered from various sources and analyzed using descriptive statistical methods (if applicable). Farmers need capital for both productivity and unproductive use. Farmers need money. Centralized and non-institutional financing sources are the key sources of finance in agriculture. In recent years, the share of agriculture financed by noninstitutionalized platforms such as money lenders fell sharply from 90,9\% to 20,9\%.For scheduled commercial banks with CGR 32.05, the highest lending rate was 32.05, while for co-operatives with CGR short-term loans the lowest was 13,57\%. For long-term loans, for Planned Commercial Banks with CGR 22,74 the average outstanding debt was 22,74, while for Co-operatives it was $2.81 \%$ CGR the lowest. The share of agricultural credits slowly increased in the agricultural GDP after the 1950s and then as part of GDP as a whole until the 1980s. Advice for lenders on the internal formalities of financial institutions should improve access to institutional loans further. Microfinance and Kisan Credit Cards (KCC) should be adopted and simplified in order to alleviate the suffering of low, poor, and easily linked tribal farmers within the Self Help Group (SHG).
\end{abstract}

KEYWORDS: Agriculture, Finance, Institutional and Non-institutional Sources \& Kisan Credit Card

Received: Jun 08, 2020; Accepted: Jun 28, 2020; Published: Sep 03, 2020; Paper Id.: IJMPERDJUN20201037

\section{INTRODUCTION}

"Agricultural finance is the study of financing and liquidity services credit provides to farm borrowers. It is also considered as the study of those financial intermediaries who provide loan funds to agriculture and the financial markets in which these intermediaries obtain their loanable funds." [1]

Agriculture is a major feature of the Indian economy, providing livelihood for a large segment of the population. According to the Census of 2011, about 55\% of all jobs are in agriculture and the related operations.The number of workers working in the agricultural sector, however, has decreased. According to the 2015-16 Labor Bureau Survey, $46.1 \%$ of the population is working in the agricultural and its supportingactivities. Furthermore, according to an ILO estimate [2] the proportion of total jobs in the agricultural sector in 2018 was approximately 44 per cent.

According to the 2015-16 Agriculture Census the overall number of agricultural properties in the country was 146 million and in 2015-16 the gross operating area was 157.14 million hectares.Small and marginal assets (0-2 hectares) accounted for 86.2 percent, compared to 47.34 percent in 2015-16, respectively. The gross property in 
possession was 1,08 hectares in 2015-2016.

Agriculture has an important part in Indian economy growth. Nevertheless, agriculture's contribution to GDP is falling.It was $52 \%$ in the 1950 s ;30\% in the 1990s and less $20 \%$ after 2010[3].Agriculture \& Allied GVA's share of total GVA at 2011-12 prices was 14.4 per cent in 2018-19[4] and 16.14 per cent at current prices. [5]

\subsection{Overview of India's Agricultural Finance}

Indian farming and the associated sector primarily cover four operations, including crops, livestock like cows, forestry, and fisheries.The central government has supported policy drives that led to revolutions in agriculture production at different times in past decades, such as the green revolution in wheat and other grains, the White Revolution in milk products, the gene revolution to encourage high-quality cotton production and the blue revolution that has focused its focus on fisheries.As a result, not only has the agriculture sector been self-sufficient, it has also come out as the largest exporter of many farm products such as corn, marine goods, etc.

Without the steps of GoI and Reserve Bank of India on agricultural credit, the above developments would not have been feasible.In recognition of the importance of institutional credit in the promotion of sustainable farming development, the All India Committee for Rural Credit (AIRCSC, 1969-1954) had provided a fundamental mechanism and institutional structure to provide a clear distribution of loans for financing agriculture and related activities. The cooperative organization had taken the responsibility of supplying the farmers with production credit until the late 1960s. Nationalisation of commercial banks happened from 1969 to 1980 with governments aiming to enforce social regulation.Therefore, RRBs were set up as alternate institutions for rural credit delivery in 1976. Such changes have culminated in a major shift in the supply of institutional loans to the farming sector.As a result, the structured institutional outlets gradually fulfilled the credit requirements of the farmers. The nation slowly moved toward a multi-faceted policy to meet the farmers' credit needs.

At its July 1968 meeting the National Credit Board stressed the need for corporate banks to expand funding participation in the priority sectors mentioned, namely agriculture and MSMEs.The key sectors were listed formally in 1972. It used the analysis of success in the specified prioritization sectors of the Bank of Reserve proposed in May 1971 by the Informal Research Group on Statistics.Throughout the years, it has grown to focus on certain sections of society that have been unable to join the financial growth of the country such as farmers who are unable to get loans and are excluded from the financing opportunities which were becoming available to the rest of the country.

The influence of the structural framework has primarily been directed at using the agricultural sector 's organized credit. The SCBs have made outstanding strides in agriculture and associated tasks. In 1981, a total of 37.71 trillion (approximately 16 percent of agricultural GDP in 1980-81) was raised in 2017-18 to \$113694.56 trillion (about 16 percent of total bank loans), i.e. $\$ 86254.25$ trillion and about 51 percent of existing Agriculture \& Allied GVA.

\subsection{Issues and Challenges of Agricultural Finance Growth}

Notwithstanding the remarkable rise in structured farm credit, there are many concerns and challenges mentioned below:

- Credit Reach -From the 2016-17 NAFIS Study on the average loan received by agriculture dependent households, it is seen that $72 \%$ of the credit demand was met from institutional and $28 \%$ through non-institutional sources.However, in the lack of a clear regulatory system and deficiency of documents concerning their farming 
operations, tenant farmers / owners / farmers with oral leases / landless labourers face difficulties in obtaining institutional loans.According to the annual return of PSL (2015-16), just $41 \%$ of marginal and small farmers could get support from banks in the public and private sectors. In addition to these credit accessibility issues and difficulties, the portion of credit in allied operation was sub-parwhen compared with its share infarm production.

- Regional Disparity in Agricultural Credit -Some of the states have a significant share of $10 \%$ of the overall credit for agriculture, relative to those who are just $0.5 \%$ or less. However, in some countries, such as Bihar and Jharkhand etc., bank credit to farmers did not equal the share they earned in agricultural output.

- Loan Waiver- Loan guarantees declared by incoming or incumbentpolitical parties have impacted the credit quality as in hope of a loan waiver, many farmers are deliberately delaying repayment. It has negatively impacted lenders' financial records and their potential chances of making use of fresh loans for agricultural purposes resulting in a further weakening of credit availability, clearly apparent from the NPAlevel,which is, 8.44 per cent in the agricultural sector as of March 31, 2019. To address these concerns, in its Monetary Policy Committee (MPC) meeting held in February 2019, the Reserve Bank of India formed a "Internal Working Group to Review Agricultural Credit" to determine the reasons for inequality between regions and other things relevant to agrarian credit, alsothe Group would recommend workable solutions to resolve the barriersto access for the farmers in the institutional agriculture loans market. At the internal working group's first meeting it was agreed that the focus of the review would cover the following:

- Credit reach: institutional credit; its measures plus the factors/drivers that influence reach of aforementioned credit

- Cost effective and inclusive system: ease of credit and inclusiveness

- Credit discipline: impact of loan waivers on state finances and agricultural credit

\subsection{Impacts of Trends on Agricultural Credit}

Credit plays a critical role in agriculture and rural economy, and is an important part of the rural economy's cycle of modernizing agriculture and marketing. Agricultural credit program with layout top down. This goes on from the banks involved. The function of the Indian agricultural credit program is shown in figure. 


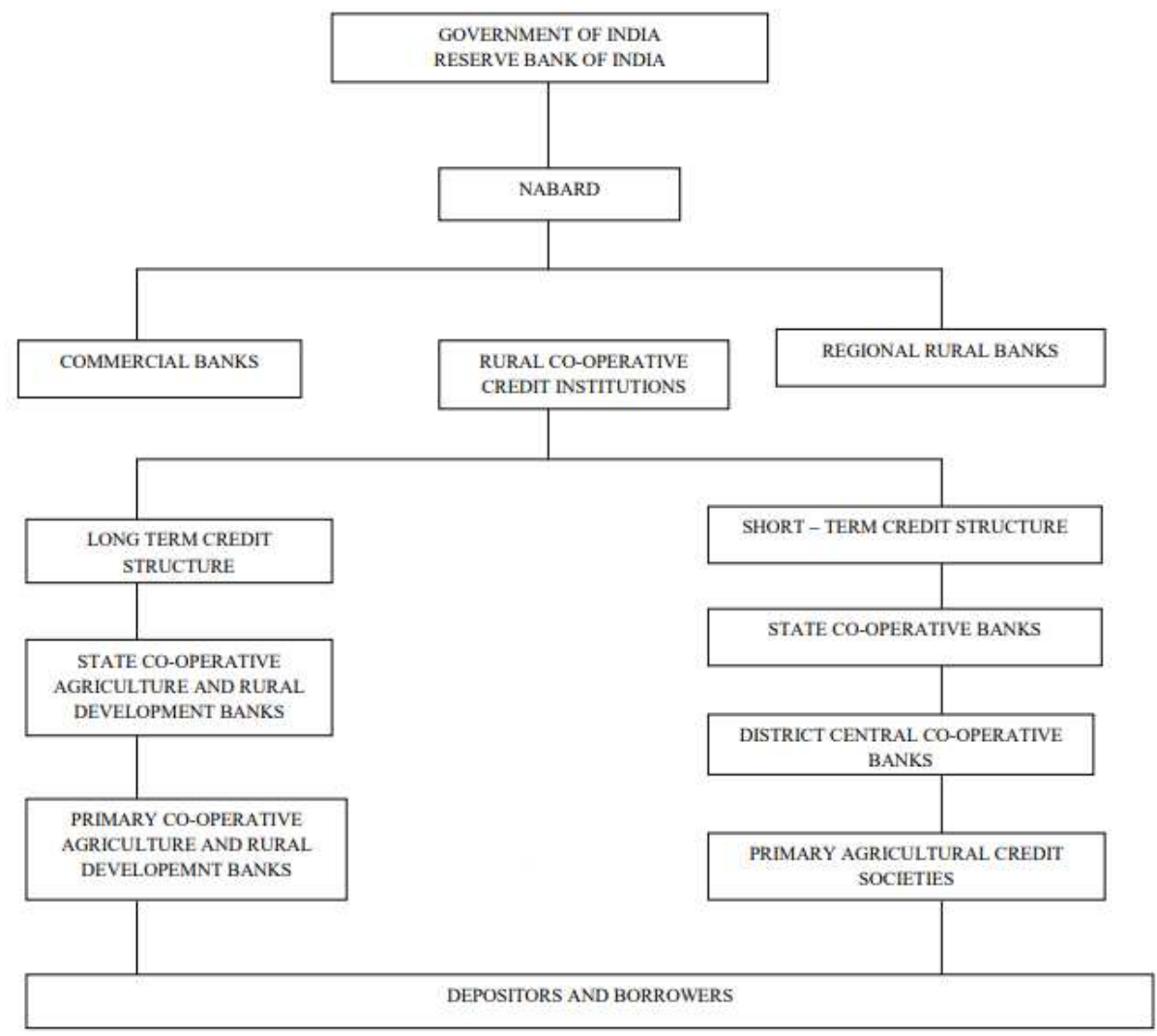

Figure 1: Structure of Agricultural Credit System in India.

To understand the effect of agarian credit and its output with respect to agarian GDP of the policy milestones mentioned above, the ratio of agarian credit to agarian GDP was determined considering the outstanding agricultural loan as well as the disbursement. The accompanying figure shows two line graphs for the same.

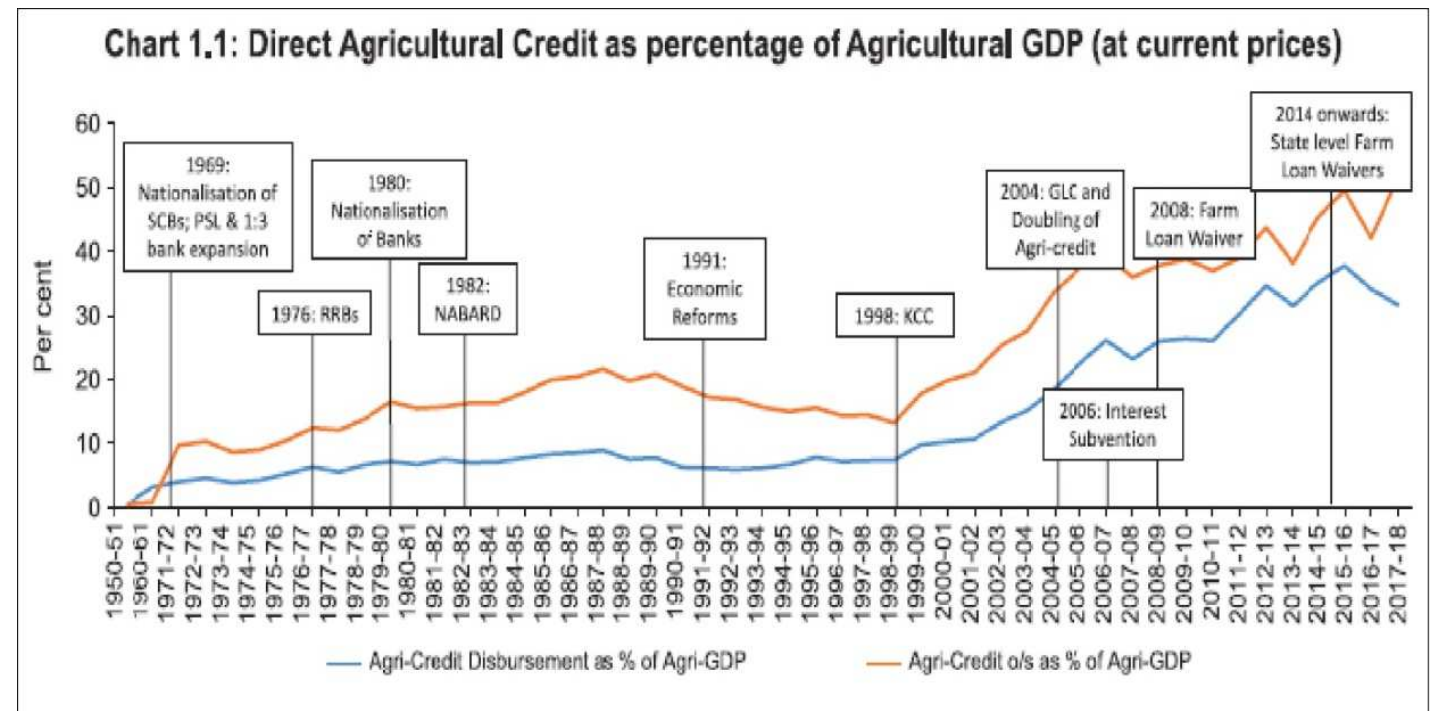

In 1950-1951, the ratio of unpaid Agri-Credit to Agri-GDP was 0.6\%, and in 1971-1972 was 9.81\%. The ratio indicates an rise of 21.76 percent after 1972 and 1987-1988. From the 1950's to the 1980's, the remarkable achievement of agrarian credit against agricultural GDP was credited to the nationalization of banks and the introduction of RRBs which widened the country's formal loan reach.The reversal pattern in the figure, however, started from 1990-91, and in 1998-99 it dropped to 13.34 per cent.The launch of KCC was a significant booster for agricultural credit as the ratio steeply 
increased post 1999 and went up to 39.55\%,resulting in a shift to expand the access of credit to the agrarian population.Many other policy measures were started in 2004-05 and played a significant role. Following years the ratiowent up to $49.63 \%$ for $2015-2016$ even upto $51.56 \%$ for $2017-2018$, following a fluctuating pattern. The graph shows that, except for situations in which all differ, both the distribution of the available agricultural credit and the charge as an agri-GDP proportion is comparably similar.The reasons for this may be the declaration of loan guarantees that adversely affected the lenders' repayment conduct and also made banks reluctant to fresh financing.Notwithstanding this remarkable achievement, the reliance of farmers on informal sources has continued over the years, though reduced to some degree. [7]

Agricultural loans can be categorized into: institutional and non-institutional agrarian credit.Institutional outlets are the government and cooperative societies, corporate bank like the Local Bank, Lead Bank. Traditionally, rural agrarian credit needs were met in the 1950s primarily by local money lenders. While farmers had easy funding, high interest rates combined with an ignorance caught them in a debt trap that put them at the mercy of the money lenders. This situation changed with the transformation of the financial system through government interventions and institutional sources, particularly through commercial banks, were the main sources of agricultural finance.

Non-institutional outlets were at the forefront in 1951, providing for $90 \%$ of the agrarian debt, according to AIDIS research, but by 1981 they were only providing 37\% and by 1991, 35\%.We see a reversal, from $35 \%$ in 1991 to 39 per cent in 2002, which went and dropped to $36 \%$ in 2013. According to the 2016-17 NAFIS survey, informal sources of credit provided for $28 \%$ in 2015 . In comparison, the institutional credit provided for 10.2 percent in 1951 to 63 percent in 1981 , and after that it fell.

\section{REVIEW OF RELATED WORK}

Sharma and Prasad (1971)[8] claimed that implementing state-of-the-art technologies without credit facilities would have no major impact on farmers' profits. Agriculture credit has a strong relationship to farm production at the income level and to the growth of agriculture.

Naryanan (1987)[9] said that small, marginal farmers and farmers were the bulk villagers who took loans. Furthermore, he observed that the incomes of recipients did not increase because of inadequate loans.

Binswanger and Khandker (1992)[10] noted that the impact of the increased rural finance on production and employment was far smaller than in the non-farm market. The impact on crop production is not high, given the fact that the use of fertilizer and private investment in machinery and livestock has greatly expanded credit to agriculture.High effect on inputs and minimal impact on production simply means that increased capital spending has become more important than growing crop output in substituting agricultural labour.

The National Agriculture Commission (1976, A.Ranga Reddy, 2004)[11] has stated that Rs. 9, 400 crore is the minimum credit demand for agriculture. Nevertheless, for 1984/85 the Planning Commission had an target of RS. 5415 crores, and between 1985 and 1985 the actual loan allocation was RS. 6167 crores. While the target number for the Planning Commission for 1984-85 was overtaken by the real disbursement, the expected number by the National Commission was not met.

Burgess and Pande[12] observed that a $1 \%$ rise in rural banked areas was essentially $0.4 \%$ lower in rural deprivation and a $0.30 \%$ higher in total growth. Development results should largely be accounted for by improvements in non-agricultural investment - suggesting not only an rise in farm incomes but also a diversification of revenues in rural 
India.

Mohan (2006)[13] looked at total farm development and institutional loan. He argued that net agricultural loans decline in proportion to the gross loan payments. He argued that there is no issue as the portion of structured loans is that in agriculture 's GDP. This demonstrates that while the loan is growing, the assessment of output figures does not necessarily have an impact which highlights credit limitations.

Golait (2007)[14] discussed agrarian credit problems in India. The study showed that credit distribution appears to be insufficient for the agricultural sector. It appears that on different grounds, the banking system always hesitates to offer loans to small and marginal farmers.There were proposals for coordinated efforts to increase the credit for agriculture and for the growth by upgrade of technology and associated methods, new advances in product design and production systems. Enabling credit across several vertical dimensions more tightly aligned with farmers would provide critical inputs and/or provide methods for processing their produce, which would greatly enhance the credit situation in agriculture.

Sreeram (2007)[15] found that expanded production and controlled credit prices tend to improve productivity and well-being farmers'as credit is a very vital and most concerning sub-component of overall investment. Borrowings in the formal and informal room may potentially be from several outlets. A part of the subcomponent are the loans from structured sources.The causality is much more difficult to determine despite data gathered mainly from organized debt collection systems and measures of a decreased official credit as a proportion of the overall debt. He also noted that it is difficult to determine, even though there is plenty of evidence, any cause of variation in crop paernst, land keeping, productivity, regional farming. He argued that the productivity dilemma could not be addressed until spending on other auxiliary services is done.

In the context of Basel 2nd rules, Antony and M (2007)[16] made an effort to price loans and develop a model for the same. The payment for a loan consists of the price of percentage costs, the profit premium of a proportion and the economic dimension of value added. The risk factor is that the predicted loss of component is measured and potential risks of premiums depend on the loss likelihood and probability.

All of India's Rural Credit Assessment Committee (1967)[17] expected Rs . 2000 crored short-term credit requirements in 1973-74, while Rs. 589.30 crores.i.e. was the real short-term institutional credit allocation. $42.97 \%$ of measured parameters.

\section{PROPOSEDWORK}

This paper structurally reviews existing contributions in agricultural finance system. In the next stage it conceptually synthesis existing contribution into conceptual framework of Digital Finance in Agricultural Sector. It mainly focused on contribution of digital finance in agriculture.

The analysis is done to find the following results:

- Research the disparity between Agricultural credit conditions and availability.

- Over the years, the growth of farm credit among smallholder farmers, marginal farmers and big farmers.

- Search on topics, questions, patterns and causes pertaining to Indian agricultural credit.

The research includes secondary figures from RBI and several comparative reports by the National Bank of 
Agriculture (NABARD) from several sources, including statistical information on agriculture on a glance, gathered by the Department of Agriculture and Cooperation, the Ministry of Agriculture, and the reports on currency and finance.

\section{Research the Disparity between Agricultural Credit Conditions and Availability}

Agricultural Credit is the amount of investment funds made available out of resources outside the farm sector for agricultural production. Agricultural Finance is a separate field of study for organizations and farmers dealing with lending and borrowing. The criteria and availability are calculations dependent, respectively, on the following considerations.

- $\quad$ Agriculture credit disbursement

- Loan distribution.

\section{- Agriculture Credit Disbursement}

Every year, the government sets agricultural loan disbursement goals for the banking sector and banks have regularly met those goals. The specifics of government-specified agricultural credit goals and the Banks' achievement over the past three years (2016-17 to 2018-19) as published by NABARD are as follows:

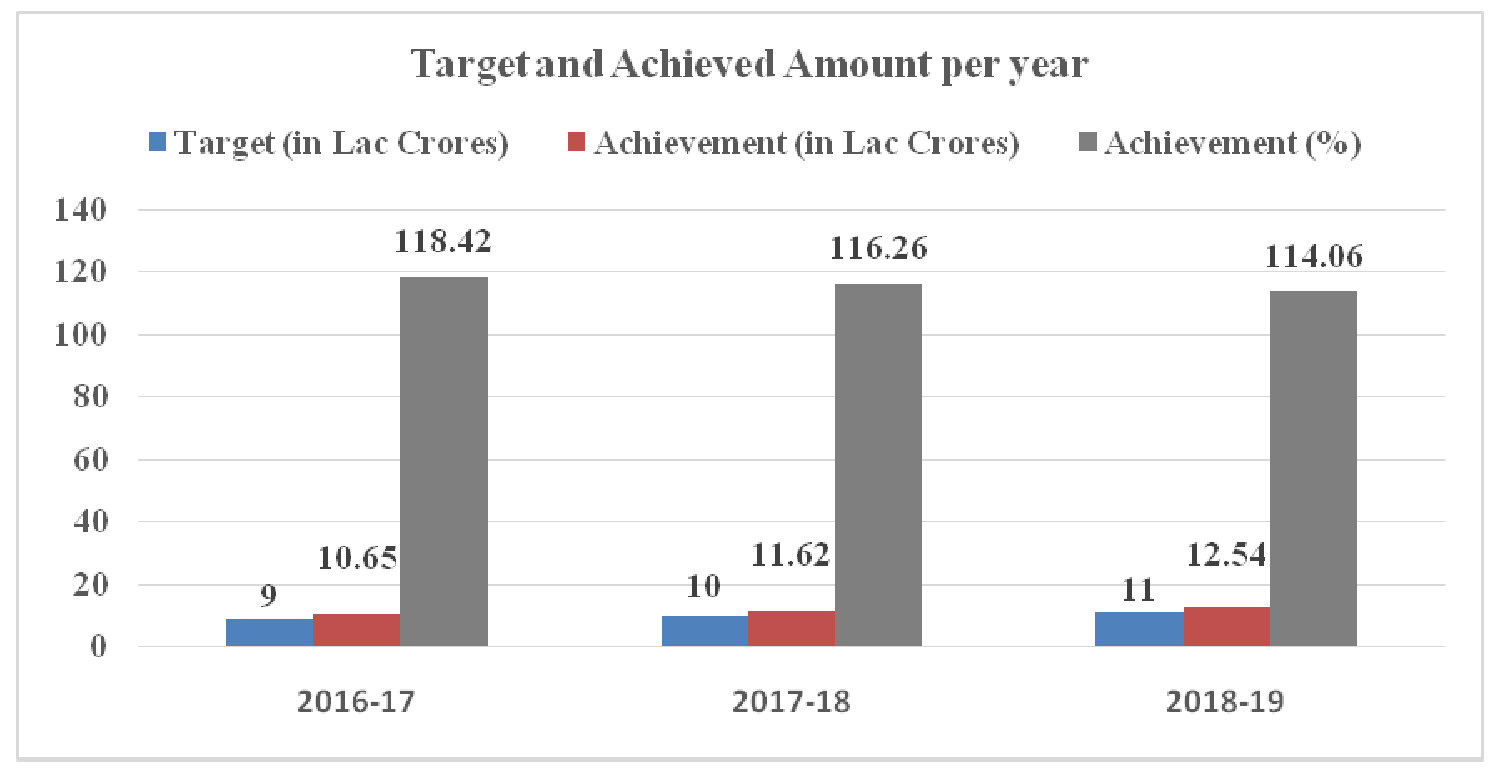

Figure 2: Target and Achieved Amount Per Year.

\section{- Loan disbursed}

The statistics from NABARD show that the total amount of loans paid in these three years to farmers and the SF / MF share in them have been the following: 


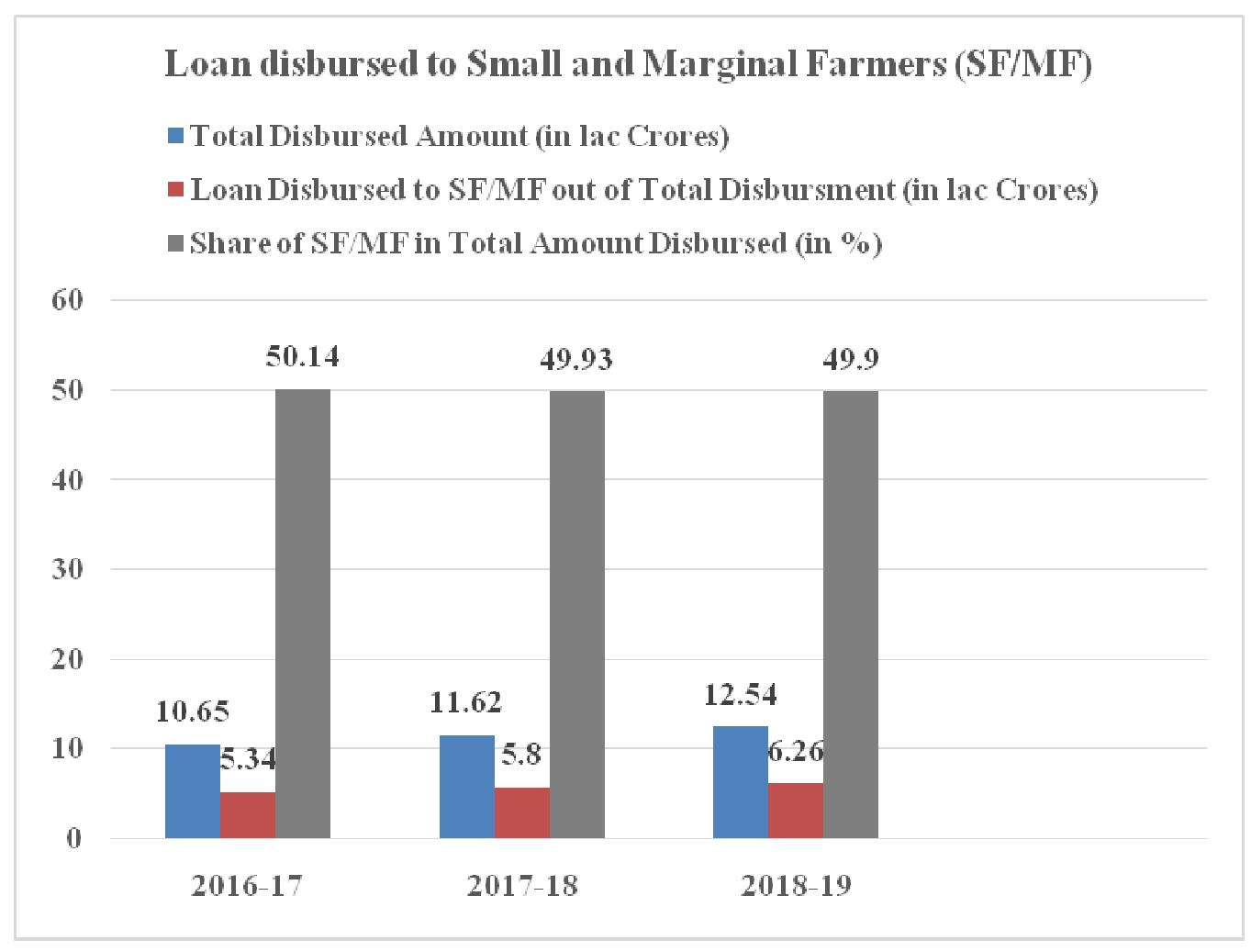

Figure 3: Loan Disbursed to Small and Marginal Farmers (SF/MF).

\section{Over the Years, the Growth of Farm Credit Among Smallholder Farmers, Marginal Farmers and Big Farmers.}

Farmers are largely engaged in subsistence farming due to a number of constraints such as limited land holdings, biased tenure systems, ineffective water management, inadequate access to inputs, inadequate availability of quality inputs, inadequate availability of affordable packages, lack of timely help, lack of information, lack of friendly technology, etc.Due to many of these restricting factors, small and marginal farmers are suffering from low productivity, yield volatility, low wages, lower income and reduced living standards.

Contribution to the growth of agricultural credits.

Among other issues, the GoI / RBI/NABARD took the following big steps to provide farmers with trouble-free crop loans, including SF / MF:-

- To ensure a subsidized rate $7 \%$ a.o. of agricultural credit is available. A rate subsidy scheme for crop loans up to 3.00 lakh has been launched by the Government of India through the agriculture department. The scheme provides banks with an annual interest payment of 2 percent for the use of their own assets. Farmers get an additional 3\% credit for paying back the debt right away, which ensures that the effective cost is lowered to $4 \%$.

- RBI guidelines provide that domestic commercial banks shall lend farmers $18 \%$ of their Balanced Net Bank or their Off-Balance Sheet Credit, selecting the higher one. For loans to small and marginal farmers like farmers without land, tenant farmers, oral leasing and share farmers, the sub-target is also proposed at eight percent. Regional rural banks are also subject to the same laws.

- The Kisan Credit Card (KCC) scheme has given a flexible limit of '10,000-50,000' to marginal farmers (like Flexi KCC) dependent on land and crops planted. The valuation of land is isolated from resources such as post-harvest 
warehouse credit requirements, etc.

- In response to extending the scope of the organized financial system to SM and neglected growers, RBI agreed to increase the threshold higher from 1 lakh to 1.6 lakh for no collateral farm loans.

- The clause of the "no due" certificate has now been discharged for small loans up to 50,000 to small and marginal farmers, which are issued with a simple self-declaration from the farmer.

- To put low, marginal tenant producers, oral lessees into the institutional credit fold Joint Liability Groups were created by institutions.

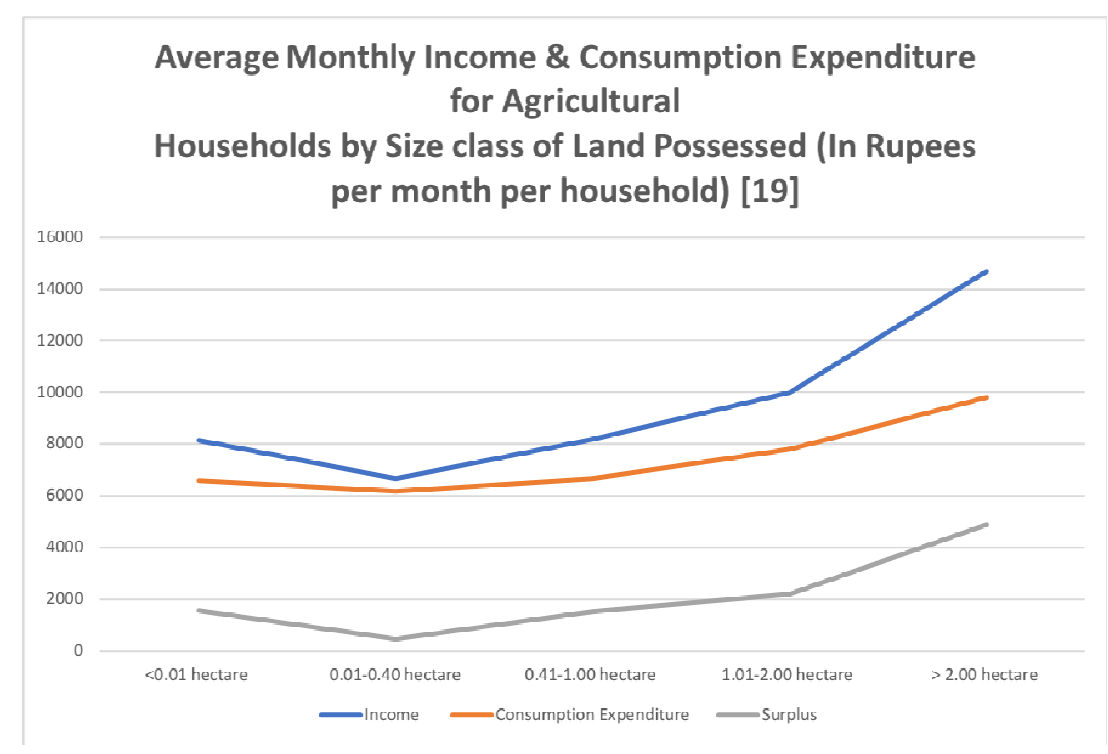

In order to examine potential trends, the position of farm households regarding the mean income and spending was further evaluated by land size.The figures mentioned were set out in above figure. The aggregate findings indicate a strong correlation from monthly consumption spending between owned land size and the revenue surplus.Excluding the size class with less than 0.01 hectare of land, household income surplus climbs with the growth in land area owned and indicates a steep increase in the $>2$ hectare class.

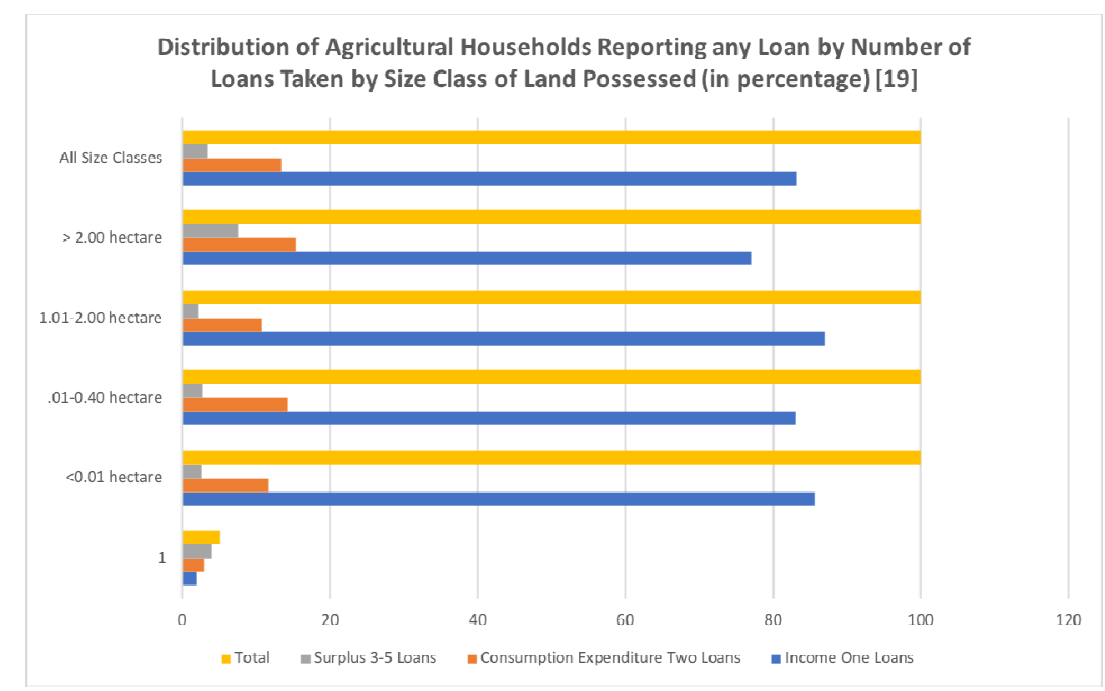


More research was conducted to assess if there was some rise in the amount of loans taken with land size changes. The findings gathered are outlined in table 2. The households with more than 2 hectareof area distinctly stand out, demonstrating a notable divergence from the overall pattern. A loan was reported by only about $75 \%$ of families, two loans were reported by $15 \%$ and three to five loans by a little $7 \%$ in the year in question.

\section{Proportion Of Household Having Valid KCC (In \%)}
$\bowtie<0.01$ Hectare
$\llcorner 0.01-0.40$ Hectare
느 $0.41-1.00$ Hectare

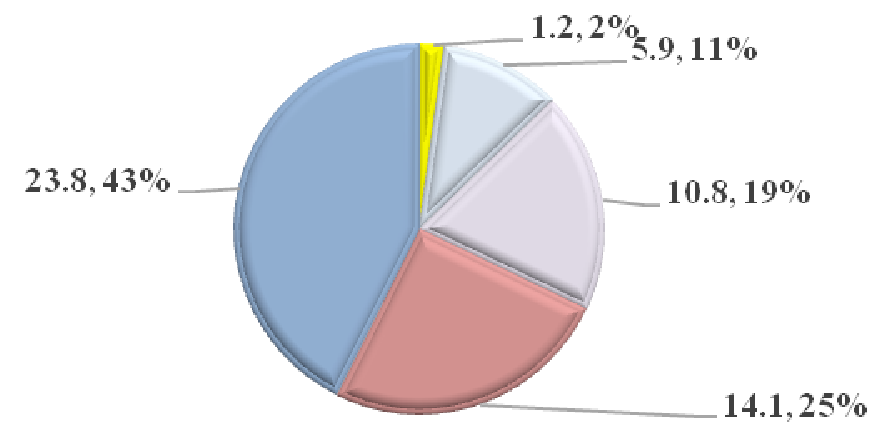

Figure 4: Proportion of Household Having Valid KCC (In \%).

As observed, the proportion of households recording KCC (penetration) increases considerably with land size changes. Householdswith more than 2 hectares of land had a peak KCC penetration of about $24 \%$.

\section{Operational Holding}

Any land that is used in whole or in part for agricultural production that is managed by one person alone or with others as one technological unit irrespective of title, legal type, size or location.

Table 1: Number of Operational Holdings as per Different Agriculture Censuses(in '000') [20]

\begin{tabular}{|l|c|c|c|c|c|}
\hline & $\mathbf{1 9 7 6 - 7 7}$ & $\mathbf{1 9 8 5 - 8 6}$ & $\mathbf{1 9 9 5 - 9 6}$ & $\mathbf{2 0 0 5 - 0 6}$ & $\mathbf{2 0 1 5 - 1 6}$ \\
\hline Marginal & 44523 & 56147 & 71179 & 83694 & 100251 \\
\hline Small & 14728 & 17922 & 21643 & 23930 & 25809 \\
\hline Semi Medium & 11666 & 13252 & 14261 & 14127 & 13993 \\
\hline Medium & 8212 & 7916 & 7092 & 6375 & 5561 \\
\hline Large & 2440 & 1918 & 1404 & 1096 & 838 \\
\hline
\end{tabular}




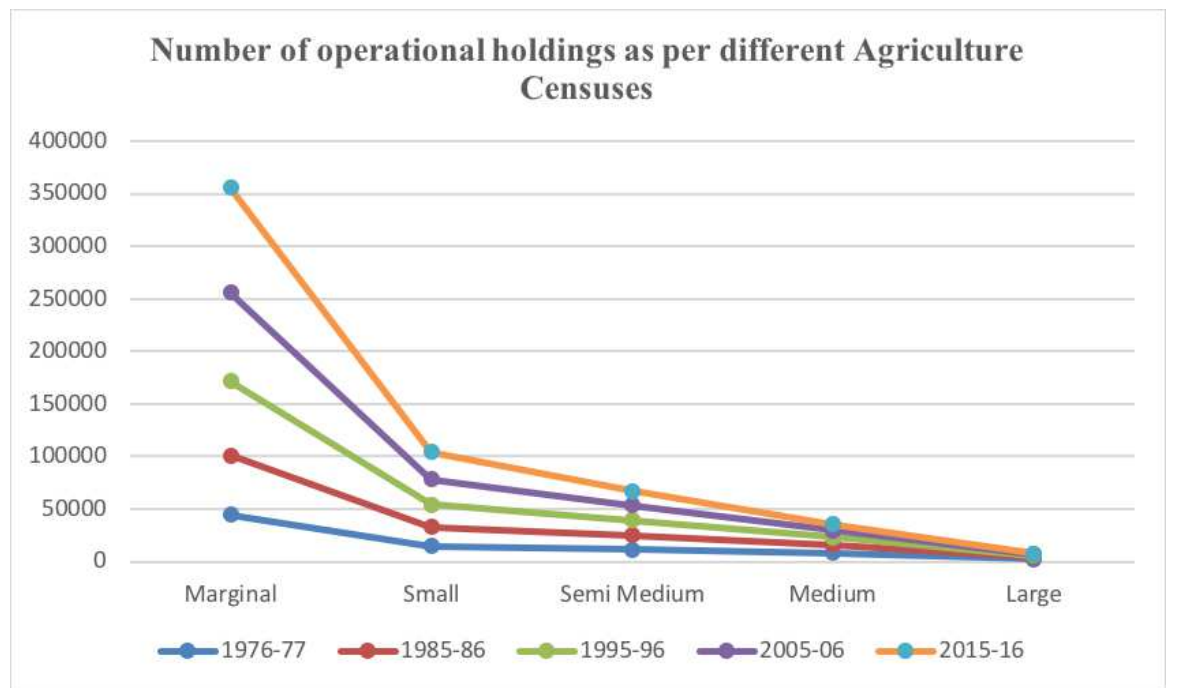

Figure 5: Number of Operational Holdings as Per Different Agriculture Censuses.

Credit plays a small part in promoting agricultural development. Agriculture 's credit volume has increased exponentially over the years, which means that agricultural credit performance has deteriorated to produce agricultural production.

\section{Search on Topics, Questions, Patterns and Causes Pertaining to Indian Agricultural Credit}

Over time, the farmer credit programs have suffered from a range of setbacks, such as restricted outreach, fragmented loan supply in various areas, sectors and parts of the agricultural population, lower loan recovery, increased asset nonperformance, and institutional losses, etc.Another problem faced is that formal sourcesof credit do not advance agricultural credit at the rate justified by expanded credit standards with greater use of purchasing inputs. Also in some other agriculturally-developed areas, the RFI credit for the total expense of the revenue was low and there is no sign of vacuum filled. RFIs make three key reasons for unsatisfactory rural results, mainly through commercial banks.Those are as follows:

- Low absorptive capacity in rural areas

- Unfavourable transaction costs

- High risks.

Farmers have to take resources to non-formal markets due to the unwillingness and inability of RFIs, i.e. product providers, merchants and bigger landlords to receive credit. Although receiving credit from these outlets is easy, it is a fact that the terms given are brutal. Heavily indebtedfarmers and are unable to produce sufficient output for repayment face repercussions as the default of repayment.This is no surprise that most suicide victimsin rural areasare farmers who are heavily indebted to informal credit sources. The widening inequalities between marginal, medium and major farmers remains a worry for policy makers. The vast proportion of the population in the lower income group, with a substantial share of land ownership, earns much less credit than their requirements.

\section{CONCLUSIONS}

Over the last decade, the volume given in the form of loans and advances to the agricultural sector has risen. In addition to this, government has taken many steps to improve the availability to credit to the country's farmers. Government has also launched Farm Credit Program, Interest Subsidy for Farmers, Extensions of Interest Subsidy for Post-Harvest Loans, 
Collateral Free Loans, Interest Subsidy for Loan Restructuring in Drought Prone Areas, Kisan Credit Card System, Agriculture Debt Waiver, Debt Relief System, etc.It can also be seen from the above data that while the amount given to the agricultural sector is increased year after year, after six decades of independence, the target for agricultural development is still not achieved.

Above all, small and marginal farmers remain poor lenders in the banking par-lance, although it was expected that these banks would take care of the farmers' credit needs at the time of nationalisation. After 50 years of planning their reliance on informal economies doesn't augur well. Both of these realities are hidden by systematic extension of systemic outlets. Their success is subject to severe scrutiny, from the qualitative perspective.

\section{FUTURE SCOPE}

The ambitious target of India to double agricultural income by 2022, with increased spending in agricultural facilities for irrigation, transportation, and cold storage, is probable. In the Indian agriculture market, an increased traction is anticipated in the coming years.Yields are expected to rise for Indian farmers due to increased used of Genetically modified crops. One such crop is an early muturing variety of pulses which has increased yields manifold and it is expected india will be self-sufficient in pulses. This coupled with rising MSP will help farmer incomes. The introduction of food protection and quality management systems, such as Total Quality Management ( TQM), namely ISO 9000, ISO 22000, hazard identification and control points, GMP and Good Hygienic Practices (GHP), would in turn have a range of advantages. The US\$ 60 billion threshold is projected to hit Indian agri-exports by 2022.

\section{REFERENCES}

1. Choubey B.N. (1983), “Agricultural Banking in India”, National Publishing House, New Delhi.

2. $\quad$ https://data.worldbank.org/indicator/SL.AGR.EMPL.ZS

3. Ministry of Statistics and Programme Implementation

4. Salunkhe, Harshal Anil, and B. B. Deshmush. "Impact Of Subsidy On Agriculture Sector In India-An Analytical Study." International Journal of Agricultural Science and Research (IJASR), 4 (2), 915 (2014).

5. Economic Survey, 2018-19, Volume II.

6. Source: Press Note on Provisional Estimates of Annual National Income, 2018-19. Figures are Provisional.

7. Handbook of Statistics on Indian Economy, 2017-18

8. RBI Report of the Internal Working Group to Review Agricultural Credit, 2019.

9. Beg, S. A. N. A., and NaushadulHaqueMullick. "Increasing financial inclusion through Islamic banking in India." International Journal of Business Management and Research 6.1 (2016).

10. J.B. Sharma and B. Prasad (1971). “An assessment of production credit needs in developing agriculture economies, 26(4), 1971. P. 503-511.

11. Naryanan (1987), "Problems of agriculture loans", Kurukshetra, 35(7): 17-18.

12. Binswanger, H. and ShahidurKhandker (1992). 'The Impact of Formal Finance on Rural Economy of India', World Bank, Working Paper No. 949. 
13. Olagunju, F. I., et al. "Impact of Bank of Agriculture Limited (BOA) on poverty status of small scale farm households in Southwestern Nigeria." International Journal of Accounting and Financial Management Research 3.1 (2013): 1-10.

14. A. Ranga Reddy (2004). "Rural Banking and over dues management, Mittal publication; New Delhi, P. 74-75.

15. Burgess, Robin and RohiniPande (2005). 'Do Rural Banks Matter? Evidence from the Indian Social Banking Experiment', American Economic Review, 95:780-795.

16. Mohan, Rakesh (2006). 'Agricultural Credit in India - Status, Issues and Future Agenda', Economic and Political Weekly, 41: 1013-1021.

17. Golait, R. (2007). 'Current Issues in Agriculture Credit in India: An Assessment', RBI Occasional Papers, 28: 79-100. Government of India, Economic Survey', various issues.

18. Barot, Haresh, and Kundan Patel. "Agriculture Finance in India-Issues \& Future Perspectives." International Journal of Business and General Management 4.6: 5-10.

19. Sriram M. S. (2007): 'Productivity of Rural Credit: A Review of Issues and Some Recent Literature', Indian Institute of Management Ahmedabad, Working Paper No.2007-06-01.

20. Antoney PV and MR (2007). A model for pricing bank loan. Mgt. Accounting 42:261-265.

21. Reserve Bank of India, (2004). 'Report of the Advisory Committee on Flow of Credit to Agriculture and Related Activities from the Banking System' (Chairman: Prof. Vyas).

22. https://pib.gov.in/Pressreleaseshare.aspx?PRID $=1576498$

23. NABARD All India Rural Financial Inclusion Survey 2016-17

24. Agriculture Census 2015-16 
